\title{
Public Deliberation, Affirmative Action, and the Supreme Court
}

\section{Citation}

Cass R. Sunstein, Public Deliberation, Affirmative Action, and the Supreme Court, 84 Calif. L. Rev. 1179 (1996).

\section{Published Version}

http://scholarship.law.berkeley.edu/californialawreview/vol84/iss4/7/

\section{Permanent link}

http://nrs.harvard.edu/urn-3:HUL.InstRepos:12921737

\section{Terms of Use}

This article was downloaded from Harvard University's DASH repository, and is made available under the terms and conditions applicable to Other Posted Material, as set forth at http:// nrs.harvard.edu/urn-3:HUL.InstRepos:dash.current.terms-of-use\#LAA

\section{Share Your Story}

The Harvard community has made this article openly available.

Please share how this access benefits you. Submit a story.

\section{Accessibility}




\section{California Law Review}

Volume 84 | Issue 4

Article 7

July 1996

\section{Public Deliberation, Affirmative Action, and the Supreme Court}

Cass R. Sunstein

Follow this and additional works at: http://scholarship.law.berkeley.edu/californialawreview

\section{Recommended Citation}

Cass R. Sunstein, Public Deliberation, Affirmative Action, and the Supreme Court, 84 CAL. L. Rev. 1179 (1996).

Available at: http://scholarship.law.berkeley.edu/californialawreview/vol84/iss4/7

This Article is brought to you for free and open access by the California Law Review at Berkeley Law Scholarship Repository. It has been accepted for inclusion in California Law Review by an authorized administrator of Berkeley Law Scholarship Repository. For more information, please contact jcera@law.berkeley.edu. 


\title{
Public Deliberation, Affirmative Action, and the Supreme Court
}

\author{
Cass R. Sunstein $\dagger$
}

INTRODUCTION

In this Essay, I make a simple and somewhat impressionistic argument. I start with the suggestion that the issue of affirmative action should be settled democratically, not judicially. Certainly the Supreme Court should not invalidate most race-conscious remedial programs. But until recently, there has been little or no sustained democratic deliberation on the issue. The citizenry's ainbivalence about-or hostility toward-affirmative action has been expressed mostly in private and not in public arenas. The enormous diversity of affirmative action programs, not to mention the separable justifications for and variable efficacy of each program, has not received much public attention. Some programs work well; some do not; and neither empirical data nor public judgments about their content and value have been reflected in program design.

In these circumstances, the Supreme Court's apparently odd behavior-its meandering course, its refusal to issue rules-in the affirmative action context might be defended as performing a valuable catalytic function. The Court's willingness to hear a number of affirmative action cases, and its complex, rule-free, highly casuistical ${ }^{1}$ opinions, have had the salutary consequence of helping to stimulate public processes and directing the citizenry toward open discussion of underlying questions of policy and principle. In these ways, the Court's route has been far preferable to the most obvious alternatives: validation or invalidation of most affirmative action prograins pursuant to clear doctrinal categories.

Copyright (c) 1996 California Law Review, Inc.

$\dagger \quad$ Karl N. Llewellyn Distinguished Service Professor of Jurisprudence, University of Chicago Law School and Department of Political Science.

1. By "casuistry," I mean decision by reference to the details of particular cases, rather than by reference to rules or theories. See generally AlbERT R. JonSEN AND STEPHEN E Toulmin, ThE Abuse of Casuistry (1988). 
That, in a nutshell, is the argument to follow. ${ }^{2}$ I do not claim that the Court has always been self-conscious about the virtues of casuistry thus described. But if the point is correct, it bears a great deal on the relations between the Court and a well-functioning system of political deliberation. It connects, for example, to current debates about the relationship between the Constitution and discrimination on the basis of sexual orientation; here too, the Court might use a casuistical method to spur public discussion. There are, however, serious questions about whether current public processes are sufficiently deliberative, especially in the area of affirmative action.

\section{I}

\section{Social Norms and Public Debate}

People often think one thing but say another, because of the effects of social pressures and social norms on what can be said in public. ${ }^{3}$ For example, in most contemporary American circles, a strong social stigma agamst anti-Semitic statements exists; people who thimk anti-Semitic things are unlikely to make such statements on television or in a public debate. In many groups where religious convictions are both deep and widespread, people cannot confess their uncertainty about whether God exists; they may attend church regularly despite their doubts on that score. In other places, people cannot acknowledge that they are deeply religious; in such places, social norms punish public declarations of religious convictions. ${ }^{4}$ The general point is simple: social norms drive a wedge between public statements and private beliefs, hopes, and convictions.

From this poiut, it emerges that "political correctness" is no isolated phenomeuon limited to left-leaning intellectuals. It is a pervasive fact of social life. It appears whenever prevailing norms discourage people from taking issue with a widely held social belief. Those interested in democratic politics should notice the omnipresent role of public constraints on public statements.

Is the existence of such constraints something to be lamented? No simple answer would make sense. Sometimes, by imposing sanctions on

2. For a similar argument, see Paul J. Mishkin, The Uses of Ambivalence: Reflections on the Supreme Court and the Constitutionality of Affirmative Action, 131 U. PA. L. REV. 907 (1983) (discussing lack of congruence between the Supreme Court's methods and results in their affirmative action cases). The argument is generalized in Cass R. Sunstein, Foreword: Leaving Things Undecided, 110 HaRv. L. REV. (forthcoming Nov. 1996).

3. An outstanding discussion of such "preference falsification" is TmUR KURAN, PRIVATE TRUTHS, PUBLIC LIES (1995), which includes a section on affirmative action at 138-41. I do not mean to endorse all of what Kuran says on that score. See Cass R. Sunstein, True Lies, The New REPUBLIC, December 25, 1995, at 37-41 (reviewing Kuran's book).

4. This is a concern in Stephen L Carter, The Culture of Disbelibf (1993). 
vicious or invidious judginents, social norms have a healthy "laundering effect." The existence of social sanctions can make people embarrassed about those judgments and eventually inake them recede or even disappear. If " $[\mathrm{h}]$ ypocrisy is the hoinage that vice pays to virtue," then social norms can identify both vice and virtue as such, and enable citizens to tell which is which. Hypocrisy can therefore have valuable social uses. It has a civilizing effect. ${ }^{7}$ It can produce justice by making unjust behavior seem vicious or otherwise unacceptable.

On the other hand, social norms of the kind I am discussing can cause damage in two different ways. First, they may prevent people froin offering arguments that are productive, reasonable, or even right. If prevailing norms are invidious or rooted in confusion, they may even perpetuate invidious or confused practices. Consider the many areas in the world where social norms strongly discourage advocacy of sex equality ${ }^{8}$ inany wornen who indicate their belief in equality run enormous risks. Second, social norms may discourage the expression of doubt, even when doubt exists and when debate is, partly for that very reason, desirable and potentially productive. In that way, prevailing norms can damage processes of public deliberation. Even if prevailing norms are not invidious on their inerits-even if they reflect clear thinking or hard won wisdom-their effects can be pernicious when they impair public deliberation. In a well-functioning democracy, facts and options are clarified through doubt, and people have a sense of what their fellow citizens think. 9 .

Of course, a certain suppression of issues and opinions stems from practical necessities. Not everything can be discussed at once. At any time, many things must be taken for granted. Some things are properly taken as so obvious that they "go without saying." But in many areas, one can safely say that democratic processes would be better if public debate focused on what really concerns people.

From the standpoint of both law and democratic theory, a great deal needs to be done on this important topic. We do not know the extent to which actual private judgments are not expressed publicly, even when they are quite widespread, and when the reason for silence is that

5. See Robert E. Goodin, Laundering Preferences, in Foundations of Social Choice THEORY 75 (Jon Elster \& Aanund Hylland eds., 1986).

6. François, Duc de La LaRouchefoucauld, Reflections; OR SENTENCES AND Moral MAXIMs, Maxim 218 (1678), quoted in John BarTLETT, Familiar Quotations 65 (Justin Kaplan ed., 16th ed. 1992).

7. See Jon Elster, Strategic Uses of Argument, in BARRIERs to Conflict Resolution 237-50 (Kenneth J. Arrow et al. eds., 1995). 105-08.

8. See Untted Nations Development Program, Human Development Report 1995, at

9. This is, of course, a standard Millian point. See JohN S. MILL, ON LdBERTY ch. 2 (Elizabeth Rapaport ed., Hackett Publishing 1978) (1859). 
social norms impose sanctions on the public expression of those judgments. It is therefore important to take account of possible disparities between what is said and what is thought. It is also important to know how wide such disparities are, whether the disparities reflect biases, and whether some social institutions or practices facilitate or inhibit open discussion.

\section{II The Supreme Court as Catalyst}

It seems obvious to say that when the Supreme Court faces a constitutional attack on a law, it has three basic options: it might uphold the law, it might invalidate the law, or it might refuse to address the issue by denying certiorari or by taking advantage of various avoidance strategies.

A detailed literature discusses the third and least obvious of these options. ${ }^{10}$ On a familiar view, the Court should often permit issues to "percolate" in lower courts and in the nation as a whole. Through this route, it can allow many forms of legal and political discussion and debate; in that way, the Court avoids premature judicial foreclosure of hard questions. The Court might take this route for practical reasons or for reasons of principle. Perhaps a firm judicial resolution would be poorly received by the community. ${ }^{11}$ Surely this point bears on possible judicial foreclosure of affirmative action programs, say, twenty-five years ago. Perhaps a judicial resolution would disserve the very cause that the Court is seeking to promote. This point has been vigorously urged in the context of abortion, where (it is said) the Court's early judicial decision in Roe v. Wade $e^{12}$ helped undermine the movement for sex equality. ${ }^{13}$ Certainly judicial decisions can have unintended social consequences, and this practical point argues in favor of judicial caution. The Court might also avoid premature foreclosure because of its own humility. The Court might lack relevant information and wait to see how a certain practice works out in reality. Or the Court might believe that certain issues are difficult from the standpoint of (legally relevant) morality and therefore, in principle, it is important to ensure that a good deal of public deliberation occurs before the Court acts.

These are important points, and as we will see they bear a great deal on the issues raised by affirmative action. But the Court actually has a

10. See generally Alexander M. B1CKel, The Least Dangerous Branch ch. 4 (1962) (discussing the Supreme Court's practice to withhold exercise of power of judical review).

11. See generally Gerald N. Rosenberg, The Hollow Hope (1991) (describing a Court "constrained" by various social and cultural conditions, including public opinion).

12. 410 U.S. 113 (1973).

13. RoSENBERG, supra note 11 , at 339 (noting that "reliance on the Court seriously weakened the political efficacy of pro-choice forces"). 
fourth option: it can issue a highly casuistical decision, one that resolves little beyond the single case, but that operates as a catalyst for public discussion. By assuming jurisdiction, by offering a ruling, but by issuing a ruling that is case-specific and along crucial dimensions not authoritative for the future, it can call public attention to a problem without foreclosing public judgment. This fourth option is especially appropriate when the Court is uncertain about whether general rules would be satisfactory, and when it believes that differences of fact and content are highly relevant to constitutional outcomes.

There is, of course, a large debate within the Court and within the scholarly community about the virtues of case-by-case particularism. ${ }^{14}$ Defenders of particularism often speak of the need to proceed cautiously in the midst of ignorance about issues not before the Court. ${ }^{15}$ But particularism also has a democratic function, and this is so in two different ways. Judicial particularists can promote democratic virtues of participation and responsiveness, by ensuring that people are not foreclosed by rulings involving previous litigants who have somewhat different complaints. The process of judicial particularism allows each person to have a day in court, invoking the distinctive features of his or her case. ${ }^{16}$ But there is an independent point. Particularist decisions allow people, through democratic processes, to continue to debate issues, secure in the knowledge that courts have not attempted to have a final say. In this respect, case-specific judgments operate as a kind of "remand" to the public for further proceedings, at least in the sense that they do not foreclose those proceedings and may even spur them through the visibility of court decisions.

In administrative law, a remand to the agency for further proceedings is an exceedingly common phenomenon. ${ }^{17}$ In the remand, the agency is permitted to do as it originally did, but it must offer a new and better justification. The court's decision is case-specific; it can easily be "distinguished" by a resourceful administrator, even on the same set of facts. Much debate exists over whether this process generally tends to

14. See Antonin Scalia, The Rule of Law as a Law of Rules, 56 U. CHI. L. REv. 1175 (1989); Kathleen M. Sullivan, The Supreme Court, 1991 Term-Foreword: The Justices of Rules and Standards, 106 Harv. L. Rev. 22 (1992); Cass R. Sunstein, Problems With Rules, 83 CallF. L. Rev. 953 (1995).

15. See Board of Educ. v. Grumet, 114 S. Ct. 2481 (1994) (O'Connor, J., concurring) (arguing that the Court's opinion does not apply the Establishment Clause test set forth in earlier line of cases).

16. See Edward H. Levi, AN Introduction to Legal Reasoning 2-6 (1949).

17. See, e.g., Motor Vehicle Mfrs. Ass'n v. State Farm Mut. Auto. Ins. Co., 463 U.S. 29, 57 (1983) (remanding to the National Higliway Traffic Safety Administration for further consideration of decision to rescind the passive restraint requirement); Industrial Union Dep't v. Am. Petroleum Inst., 448 U.S. 607, 671 (1980) (remanding to Occupational Safety and Health Administration to reconsider the permissible exposure limit established for benzene). 
work out well. ${ }^{18}$ But when it does, the remand promotes better public deliberation by drawing attention to difficulties that had not yet received adequate attention, and by helping to produce better processes of deliberation for the future. ${ }^{19}$

Much of constitutional law has a structure similar to the administrative law remand. ${ }^{20}$ Soinetimes the Court effectively "remands" issues for fresh deliberation. ${ }^{21}$ Many of the modern privacy cases involving sexual autonomy can be understood accordingly. ${ }^{22}$ In these cases, the state defended laws restricting availability of contraception by reference to the goal of preventing premarital or extramarital activity. The Court did not deny that the state has a legitimate interest in preventing nonmarital sexual activity. We do not say that a law directly punishing such activity is unconstitutional. But, the state may not attempt to promote the underlying interest through the indirect means of preventing contraception. If the state is genuinely interested in preventing nonmarital sexual relations, it must pursue that policy in a way that receives meaningful democratic scrutiny and reflects actual democratic approval of the underlying judgment of policy and principle-through the criminal sanction. The more indirect and discriminatory route of preventing contraception is an unacceptable means of pursuing the relevant end. Because of its indirection, a ban on contraceptives does not accurately reflect a democratic judgment against extramarital relations. In fact, no such judgment followed the Court's cases because the public was unwilling to use the criminal sanction to punish extramarital relations directly.

18. See Joseph L. Sax, The (Unhappy) Truth About NEPA, 26 OKLA. L. Rev. 239 (1973) (suggesting that there is "no solid evidence to support the belief that requiring articulation, detailed findings or reasoned opinions enhances the integrity or propriety of . . administrative decisions"); $c f$. Peter H. Schuck \& E. Donald Elliott, To the Chevron Station: An Empirical Study of Federal Administrative Law, 1990 DUKE LJ. 984, 1059 (1991) (reporting that their original hypothesis that agencies would seek ways to reaffirm their decisions on remand "was not borne out," and that in approximately $40 \%$ of remands, the agencies made major changes "primarily because of the remand") (emphasis in original).

19. See William F. Pedersen, Jr., Formal Records and Informal Rulemaking, 85 YALE L.J. 38, $59-60$ (1975).

20. See Robert A. Burt, The Constitution in Conflict (1992); Guido Calabresi, Antidiscrimination and Constitutional Accountability (What the Bork-Brennan Debate Ignores), 105 HARV. L. REV. 80 (1991).

21. See Alexander M. Bickel \& Harry H. Wellington, Legislative Purpose and the Judicial Process: the Lincoln Mills Case, 71 HaRv. L. Rev. 1 (1957).

22. See Carey v. Population Servs. Int'l, 431 U.S. 678 (1977) (holding that access to contraceptives is essential to the exercise of a fundamental right to procreation and is therefore consitutionally protected); Eisenstadt v. Baird, 405 U.S. 438 (1972) (finding statute permitting married persons, but not single persons, to obtain contraceptives violated the Equal Protection Clause); Griswold v. Connecticut, 381 U.S. 479 (1965) (holding a statute forbidding the use of contraceptives as unconstitutional because it violated the right of marital privacy). 
This is a controversial account of the privacy cases. But it helps make sense of rulings that are otherwise very puzzling. And at the very least, it suggests the possibility of a judicial role in catalyzing public debate through narrow rulings designed to focus public attention on the more fundamental questions.

\section{III \\ The Affirmative Action Muddle}

It is easy to be skeptical about the Supreme Court's affirmative action cases. From the standpoint of the rule of law, the cases are truly a mess. This was so from the very start. In Regents of the University of California v. Bakke, ${ }^{23}$ the Court was badly divided and could not produce a majority opinion. Of course, the often-criticized "rule" of the case was that universities may use race "as a factor" in admissions, but may not create quotas. ${ }^{24}$ While this rule has played a crucial role in American society and American debate, it represented the view of Justice Powell alone. The other eight participating justices explicitly rejected that rule. Ironically, the case stands for a proposition that only one justice thought sensible.

Bakke was not an auspicious beginning for those seeking clear rules. The Court's second affirmative action case, Fullilove v. Klutznick, compounded the problem. ${ }^{25}$ In that case, no majority spoke for the Court, no standard of review was selected for affirmative action cases, and by the plurality's own admission, its decision was highly dependent on the facts of the particular case. ${ }^{26}$ In another case with slightly different facts, the outcome might be different. ${ }^{27}$ Remarkably, during the next nine years, the Court's decisions developed no clear standard of review and seemed to turn not ou rules, but instead on a large set of factors:

-whether official findings of past discrimination had been made; ${ }^{28}$

- whether the relevant program was rigid or flexible; ${ }^{29}$

-whether the relevant program operated as a quota; ${ }^{30}$

23. 438 U.S. 265 (1978).

24. Id. at 272 .

25. 448 U.S. 448 (1980) (upholding a federal law requiring that $10 \%$ of federal funds granted for local public works be used by minority-owned businesses).

26. Id. at 486 .

27. Id. (noting that a different outcome might have been reached, for example, if the program had excluded an identifiable minority group that had been the victim of a degree of disadvantage and discrimination equal to or greater than that suffered by the groups encompassed in the program).

28. Wygant v. Jackson Bd. of Educ., 476 U.S. 267, $277-78$ (1986) (requiring an official finding of past discrimination by the government department involved before racial classifications can be used to remedy discrimination).

29. Fullilove, 448 U.S. at 490.

30. Bakke, 438 U.S. at 315-18 (Powell, J.). 
-whether the relevant program had been issued by Congress, by another politically accountable body, by a court, or by some other institution; ${ }^{31}$

-whether innocent victims were injured, and if so in a severe way; ${ }^{32}$

-and more. ${ }^{33}$

The use of these numerous factors led to surprising decisions in particular cases, and outcomes were hard to predict in advance. Notably, some of these factors relate to the nature of the deliberative process itself. The relevant cases received a good deal of public attention, but the constitutional position of affirmative action programs remained quite obscure. ${ }^{34}$

It was not until 1989 that the Court finally settled on a standard of review. In City of Richmond v. J.A. Croson Co. ${ }^{35}$ a plurality of the Court held that affirmative action programs would be subject to "strict scrutiny," at least if they had not been enacted by the federal government. ${ }^{36}$ But even while announcing a standard of review, it did so in such a way as to leave the law exceptionally obscure, and to leave the many decisions that preceded Croson in an uncertain state. ${ }^{37}$ Hence, Croson did not reject the Court's casuistical approach to affirmative action. And in Adarand Constructors Inc. v. Pena, ${ }^{38}$ when the Court finally announced that the same standard of review applied to the nation

31. Fullilove, 448 U.S. at 480.

32. Wygant, 476 U.S. at 282-83.

33. See, e.g., United States v. Paradise, 480 U.S. 149 (1987) (considering whether a raceconscious promotion system is narrowly tailored); Sheet Metal Workers v. EEOC, 478 U.S. 421 (1986) (approving affirmative action program for a union with a history of continued and egregious racial discrimination).

34. The legitimacy of affirmative action in the statutory context is more clear. United Steelworkers of Am. v. Weber, 443 U.S. 193, 208 (1979), held that Title VII does not ban voluntary race-conscious actions by an employer. I believe that the best argument for this result is consistent with the democracy-reinforcing concerns traced in this essay. In 1964, Congress made no considered judgment that affirmative action programs were unlawful. When it spoke in terms of race neutrality, it was thinking not of remedial programs, but of discrimination based on malice. See Johnson v. Transp. Agency, 480 U.S. 616 (1987) (holding that Title VII forbids discrimination against whites at least if it is not part of an affirmative action program). In the absence of a considered judgment by Congress, the Court should not ban voluntary programs of this kind. See Cass R. Sunstein, Legal Reasoning and Political Conflict ch. 4 (1995).

35. 488 U.S. 469 (1989).

36. Id. at 493-98 (O'Connor, J.) (plurality opinion).

37. Compare Joint Statement: Constitutional Scholars' Statement on Affirmative Action After City of Richmond v. J.A. Croson Co., 98 YALE LJ. 1711 (1989) (presenting the view of thirty constitutional scholars that carefully designed race-conscious remedies of state and local governments are not necessarily unconstitutional), with Charles Fried, Affirmative Action After City of Richmond v. J.A. Croson Co.: A Response to the Scholars' Statement, 99 YALE L.J. 155 (1989) (arguing that the Scholars' Statement is misleading because Croson severely limits the availability of race-based quotas and preferences).

38. 115 S.Ct. 2097 (1995). 
as to the states, ${ }^{39}$ it went out of its way to make clear that the standard would not lead to automatic invalidation, that outcomes would turn on particular facts, ${ }^{40}$ and thus that we could not foresee certain results in future cases.

As a result, there is still-eighteen years and numerous Supreme Court cases after Bakke-a high degree of uncertainty about the law governing affirmative action. The public reaction to Adarand shows that a great deal of doubt about whether affirmative action is constitutionally permissible still remains. ${ }^{41}$ Now, as before, the validity of an affirmative action program greatly depends on the particular case.

What has the Court achieved? Perhaps the Court has succeeded in invalidating the most indefensible affirmative action plans and in upholding the most legitimate. This would certamly be the optimist's view. ${ }^{42}$ But if we step back a bit, we might conclude that the Court has helped keep the nation's eye on the affirmative action issue-on the questions of policy and principle that lie behind the debate-while at the same time failing to preempt processes of public discussion and debate. Above all, the Court has done this because it has decided a large number of cases, but proceeded in a highly particularistic manner.

\section{$\mathrm{V}$}

\section{Affirmative Action and Public Debate}

\section{A. The Constitutional Attack on Affirmative Action}

It seems reasonable to think that the question of affirmative action should be settled democratically, not judicially. Despite frequent prot-

39. Id. at $\mathbf{2 1 1 7}$ (holding that all government-established racial classifications must be analyzed under the strict scrutiny standard of review).

40. The Court wrote:

We wish to dispel the notion that strict scrutiny is 'strict in theory, but fatal in fact.' The unhappy persistence of both the practice and the lingering effects of racial discrimination against minority groups in this country is an unfortunate reality, and government is not disqualified from acting in response to it.... When race-based action is necessary to further a compelling interest, such action is within constitutional constraints if it satisfies the 'narrow tailoring' test this Court has set out in previous cases.

Id. (citations omitted).

41. Justice Department Memorandum on Supreme Court's Adarand Decision, 405 LABOR Relations Rptr.: Fair Employment Practices MaNual (BNA) 221 (June 28, 1995).

42. I do not believe that this view is correct. The affirmative action program in Metro Broadcasting Inc. v. FCC, 497 U.S. 547 (1990), is probably the least defensible, but the Court actually upheld it. The Court said that the minority set-aside in the broadcasting area could be defended as a way of ensuring that the minority community would receive broadcasting of its choice. Id. But-and this is a central point- there was no requireinent that minority-owned stations provide broadcasting for minority communities. The reason that there was no such requirement was that it would, on the conventional view, violate the First Amendinent. Thus, the Court upheld the minority set-aside as a proxy (admittedly a very crnde one) for an end that was generally believed unconstitutional. 
estations to the contrary, ${ }^{43}$ the Constitution imposes no clear textual ban on affirmative action. In fact, the textual arguments are laughably inadequate. To be sure, the Constitution calls for "equal" protection of the laws; but this point is uninformative on the validity of affirmative action. ${ }^{44}$ The term "equal" cannot possibly mean "the same," if "the same" is mtended to suggest a ban on all classification. By their nature, laws classify. Even the law of equal protection classifies. Thus, it is no offense to the Equal Protection Clause if courts scrutinize sex-based classifications more skeptically than they scrutinize age-based classifications-even though this difference does not treat people "the same." The question is what the word "equal" requires in this context. Dictionaries are unhelpful here. The only way to make progress is to go outside of the text; we must look there to fmd possible understandings of the Constitution's equality principle.

Nor is it helpful to say that the Constitution speaks of "any person" rather than of groups. ${ }^{45}$ The Supreme Court, together with many scholars, appears to think that the reference to "any person" means that the clause speaks of individuals rather than of groups, and that this point counts against affirmative action. ${ }^{46}$ This claim contains some truth, but it is misleading. To be sure, "any person" may complain that a classification is constitutionally unacceptable. But on what grounds can "any person" seek special judicial assistance? Under the Equal Protection Clause, all claims of unconstitutional discrimination are necessarily based on complaints about treatment that singles out a characteristic shared by a group. A glance at the cases, or at any imaginable set of cases, shows that anyone who complains of unconstitutional discrimination is necessarily complaining about the government's use, for purposes of classification, of some characteristic that is shared by some number of group members. The question is whether the government's use of that shared characteristic is disfavored from the constitutional point of view. There is no serious question about whether the characteristics of which "any person" may complain are shared characteristics; of course they are. In this sense, claims of unconstitutional discrimination are always group-based claims, even if they are made by "any person."

43. See, e.g., David P. Currie, The Constitution of the United States: A Primer for the People 58-61 (1988); Richard A. Epstein, Forbidden Grounds: The Case Against EMPLOYMENT DisCrimination Laws 395-437 (1992).

44. See CurRIE, supra note 43 , at 58-61.

45. U.S. CONST., amend. XIV, § 1 .

46. See Adarand Constructors Inc. v. Pena, 115 S. Ct. 2097, 2111 (1995); City of Richmond v. J.A. Croson Co., 488 U.S. 469, 493 (1989) (O'Connor, J.) (plurality opinion); Regents of the Univ. of Calif. v. Bakke, 438 U.S. 265, 289-90 (Powell, J.) (1978); see also EPSTEIN, supra note 43, at 399405. 
For example, suppose that Jones has been denied a government job. As a "person," she has a right to make a complaint under the Equal Protection Clause. But everything depends on the characteristic on which government has allegedly seized. For Jones to claim heightened scrutiny under the Equal Protection Clause, she has to say something about the classification that the government has used; and she must say that the classification treats her, as a member of a certain group, in a "suspect" way. Thus she has a claim to careful scrutiny of laws disadvantaging her if those laws classify on the basis of sex. But if she invokes another characteristic, she has no such claim. The same plaintiff Jones has no right to heightened judicial scrutiny if those laws classify on the basis of age. ${ }^{47}$ She is thus entitled to a degree of scrutiny corresponding to the basis of the classification of which she complains.

In short, almost all classifications involve "groups." The issue is whether heightened scrutiny represents the appropriate standard of review for the particular classification that the government has used. The fact that the Constitution refers to "any person" is utterly uninformative regarding whether any particular foundation for classification should, or does, meet heightened judicial scrutiny. The Court's use of the constitutional text as a justification for heightened scrutiny is bad formalisin-the pretense that the legal text resolves the question when the judgment inust actually be based on other grounds.

If the text of the Constitution does not ban affirmative action, what of the Constitution's history? It might be tempting to say that it is a lesson of the Civil War that all racial classifications are unacceptable. But the history shows no such particular understanding on the part of those who ratified the Fourteenth Amendment. On the contrary, it tends to suggest that affirmative action policies were regarded as legitimate. The Reconstruction Congress that approved the Fourteenth Amendment concurrently enacted a number of race-specific programs for AfricanAmericans. ${ }^{48}$ A substantial debate about whether such programs were legitimate occurred, and the people who controlled Congress after the Civil War concluded that they were. No evidence exists in the Fourteenth Amendinent ratification debates that all race-conscious programs would be impermissible. ${ }^{49}$

History need not be decisive. Perhaps a moral argument justifies the Court in reading the text to ban affirmative action. But no clear moral argument requires courts to treat affirmative action policies with

47. See Massachusetts Bd. of Retirement v. Murgia, 427 U.S. 307 (1976) (holding that rationality review, rather than strict scrutiny, was the proper standard for age-based classifications).

48. See Eric Schnapper, Affirmative Action and the Legislative History of the Fourteenth Amendment, 71 VA. L. REv. 753 (1985) (discussing the legislative history of these programs with emphasis on the 1866 Freedmen's Bureau Act).

49. See Andrew Kull, The Color-Blind Constitution 79 (1992). 
great skepticism. Many critics of affirmative action claim that the moral argument lay at the heart of the work of Martin Luther King, Jr., and others in the civil rights movements of the $1960 \mathrm{~s} ;{ }^{50}$ but this is an historical error. Asked in 1965 whether it was "fair to request a multibilliondollar program of preferential treatment for the Negro, or for any other minority group," King flatly replied, "I do indeed." 51 In 1966, King wrote,

It is impossible to create a formula for the future which does not take into account that our society has been doing something special against the Negro for hundreds of years. How then can he be absorbed into the mainstream of American life if we do not do something special for him now, in order to balance the equation and equip him to compete on a just and equal basis?"52

In fact, King's 1964 book, Why We Can't Wait, criticized the idea that once African Americans had been granted simple equality before the law, no further action should be taken. He wrote,

On the surface, this appears reasonable, but it is not realistic. For it is obvious that if a man is entered at the starting line in a race three hundred years after another man, the first would have to perform some impossible feat in order to catch up with his fellow runner. ${ }^{53}$

The views of Martin Luther King, Jr., need not be decisive. Perhaps a moral principle of color-blindness deserves constitutional recognition; certamly this is so if it is the only intelligible principle behind the constitutional concern for racial equality. But we can identify an alternative moral principle, one that has actually been responsible for most of the movement for racial change in America, both during the Civil War and thereafter. In the area of race, a large target of the Civil War Amendments was the preexisting system of racial caste: a system that turned the highly visible and morally irrelevant characteristic of race into a systemic basis for second-class citizenship. ${ }^{54}$ The Fourteenth Amendment is best conceived of as opposing that caste system.5 And if this represents the best conception of the Fourteenth Amendment, then there is nothing fundamentally illegitimate about affirmative action programs. ${ }^{56}$ Such programs are designed to overcome caste-like features of

50. See, e.g., Dinesh D'Souza, The End of Racism: Principles for a Multiracial SoCIETY (1995).

51. Alex Haley, The Playboy Interviews 1 I5 (Murray Fisher ed., I993).

52. Martin Luther King, JR., Why We CAN'T Wait 146 (1963).

53. Id. at 147 .

54. I draw here from Cass R. Sunstein, The Anticaste Principle, 92 Mrch. L. REv. 2410, 2429 (1994).

55. See Adarand Constructors Inc. v. Pena, 115 S. Ct. 2097, 2120 (1995) (Stevens, J., dissenting); Sunstein, supra note 54, at 2439.

56. See Adarand, 115 S. Ct. at 2120 (Stevens, J., dissenting). 
existing practice. This does not mean that they are a good idea, as they may not have this effect. It may be that they are bad on grounds of policy and should be rejected in democratic and administrative arenas. But that possibility does not make them constitutionally objectionable.

In fact, the Supreme Court has yet to provide a clear explanation of the principle that requires affirmative action programs to be treated so skeptically. ${ }^{57}$ Most of its argument depends on a false claim of symmetry: if discrimination against African Americans is presumptively forbidden, how can discrimination against whites be presumptively legitimate? ${ }^{58}$ This question is anything but rhetorical. It is no better than the question, if discrimination on the basis of sex is presumed illegitimate, how can the same not be true for discrimination on the basis of age? In fact, the anticaste principle helps provide an answer to both questions, and that answer suggests that different forms of discrimination are utterly different. To be sure, the Court has referred to a set of legitimate concerns about affirmative action policies: the social divisiveness of affirnative action, the ordinary moral irrelevance of race, the fact that race is not chosen voluntarily, and the possibility that affirnative action programs will stigmatize their intended beneficiaries. But none of these points supports a convincing constitutional complaint about affinnative action. ${ }^{59}$ Many things that government does are divisive, yet they are not unconstitutional for that reason. Many characteristics that are morally irrelevant, and that are not voluntarily chosen, are used by government as classifying devices; consider height, strength, and intelligence. Affirmative action programs may well stigmatize their intended beneficiaries. But the same is plausibly true for programs that benefit children of alumni or people froin underrepresented regions, and those prograins are not, because of their stigmatizing effects, unconstitutional under the Fourteenth Amendment.

57. There is a lurking concem in the cases with interest-group power. See David A. Strauss, Affirmative Action and the Public Interest, 1995 SuP. CT. REv. 1. Undoubtedly, interest-group power does underlie some affirmative action programs. But why should this form of interest-group victory receive careful judicial scrutiny, while other forms do not?

Occasionally, the cases also suggest that racial classifications produce social division. See, e.g., City of Richmond v. J.A. Croson Co., 488 U.S. 469, 493 (1989) (O'Connor, J.) (plurality opinion); Fullilove v. Klutznick, 448 U.S. 448,545 (1980) (Stevens, J., dissenting). This may well be true. But an absence of affirmative action programs would also produce social division. In any case, many government programs appear to promote social division, and they are not constitutionally suspect for that reason. Some examples include veterans' preference laws, laws supporting public education, as well as laws supporting art and culture.

58. For an egregious example of such false symmetry, see D'SouzA, supra note 50 , which offers no argument against preferential treatment even though preferential treatment is one of the book's central targets.

59. See, e.g., Fullilove, 448 U.S. at 545 (Stevens, J., dissenting). 


\section{B. Democratic Debate and Affirmative Action}

These remarks certainly do not mean that affirmative action programs are a good idea. The range of such programs is very wide, and to make a judgment on them, it is important to have a sense of their variety and of their consequences. Such programs include relatively uncontroversial efforts to increase the pool of applicants by ensuring that the candidates are diverse; these efforts are certainly race-conscious, but at the stage of recruitment rather than actual appointment. It is hard to see why such efforts are objectionable. Other affirmative action programs include race as a factor among many others. Still other programs include rigid quota systems as well. Some programs give a minor boost to highly qualified candidates, and some allow people entry into programs for which they are ill-suited. Evaluation of such programs should depend partly on their content and their consequences, and the term "affirmative action programs" is far too imprecise to speak adequately on that score. Above all, we need to know how such programs are operating in the real world. Undoubtedly, many affirmative action programs are successful and perceived as such.

It is striking but true that until the very recent past, the nation had yet to have a sustained discussion about the legitimacy and variety of affirmative action programs and of possible alternatives. ${ }^{60}$ When Congress adopted the 1964 Civil Rights Act, discrimination against African Americans was of course the central focus of the debate. ${ }^{61}$ Affirmative action programs were in an embryonic state and did not receive much, if any, consideration. ${ }^{62}$ The first important affirmative action program was actually adopted by Executive Order ${ }^{63}$ The proliferation of such programs at the national, state, and local levels has proceeded without sustained attention to the underlying issues of principle and policy. Whatever one thinks about the legitimacy of affirnative action, this lack of deliberation is quite disturbing. ${ }^{64}$

60. See, e.g., Drew S. Days III, Fullilove, 96 YALE L. J. 453 (1987).

61. This is clear from both the majority and the dissenting opinions in United Steelworkers of America v. Weber, 443 U.S. 193 (I979). The dissenting opinion of Chief Justice Burger tries to argue that there was an explicit judgment to forbid race-conscious programs benefiting African Americans. Id. at 216-19 (Burger, C.J., dissenting). But the snippets in the history, taken in context, do not justify that conclusion. See Richard A. Posner, The Problems of Jurisprudence 283-85 (1990) (discussing Weber).

62. The debates that appear to involve affirmative action actually involved (a) federally mandated racial balance; and (b) racially-motivated actions against whites without remedial goals as in McDonald v. Sante Fe Trail Transp. Co., 427 U.S. 273 (1976).

63. See Exec. Order No. 11,246, 3 C.F.R. 339 (1964-65), reprinted in 42 U.S.C. $\$ 2000 \mathrm{e}$ (West 1994).

64. Cf. JANE J. MANSBRIDGe, WHY WE LOST THE ERA 68 (1986) (discussing the phenomenon of "decision by accretion"). 
In fact, it is plausible to think that some of the public backlash against affirmative action is attributable to the perception that the relevant programs have never been debated and defended publicly. It is not at all true to say, as many do, that affirmative action programs are a creation of federal courts; ${ }^{65}$ many such programs have their origins in private decisions or in decisions of politically accountable bodies. But the widespread perception that affirmative action programs are courtgenerated is illuminating insofar as it suggests a belief that such programs have not been ratified publicly.

\section{The Court as Catalyst in Affirmative Action}

We are now in a position to discuss the possible catalytic role of the Supreme Court insofar as that role bears on the affirmative action debate. Suppose that it is agreed that the issue of affirmative action should be decided democratically rather than judicially-but suppose, too, that institutions are operating im such a way as to ensure that any public decisions are taken in an unaccountable way, and are not really a product of democratic judgments. The Supreme Court's meandering, casuistical, rule-free path may well be a salutary way of signaling the existence of large questions of policy and principle, at least with constitutional dimensions, when those questions would otherwise receive far less attention than they deserve. Hence, the participants in Supreme Court cases have become familiar "characters" in the national debate, helping to frame discussion: people like Bakke, ${ }^{66}$ Weber, ${ }^{67}$ Johnson, ${ }^{68}$ minority construction contractors, ${ }^{69}$ and others.

Judicial signaling is especially important in a context where social norms may have an adverse effect on open public discussion. Suppose that a policy persists not because people are in favor of it, but because social norms prevent people from voicing their complaints publicly. Suppose too that these complaints are widespread. If this is so, ${ }^{70}$ there is a democratic problem that requires attention. At least as a general rule, something should be done to ensure that the issue receives public consideration. Private actors can help to remedy the situation. We might describe as "norm entrepreneurs" those people who try to activate pri-

65. See D'SouzA, supra note 50, at 291 (claiming that "racial" preferences are now widespread in private sector job hiring").

66. Regents of the Univ. of Calif. v. Bakke, 438 U.S. 265 (1978).

67. United Steelworkers of Am. v. Weber, 443 U.S. 193 (1979).

68. Johnson v. Transp. Agency, 480 U.S. 616 (1987).

69. Adarand Constructors Inc. v. Pena, 115 S. Ct. 2097 (1995); City of Richmond v. J.A. Croson Co., 488 U.S. 469 (1989).

70. See KURAN, supra note 3, at $138-41$ (discussing the reasons why people do not voice these widespread complaints). 
vate beliefs and judgments $\dot{m}$ favor of a shift $\mathrm{m}$ existing social norms. ${ }^{11}$ But official institutions can play a role as well. In particular, the Supreme Court can signal the existence of hard questions of political morality and public policy, by taking cases, drawing public attention to the underlying questions, and refusing to issue authoritative pronouncements. And if we examine the Court's practice in the area of affirmative action, we can see that the Court has operated in precisely this way. It has helped keep the affirmative action issue in the public domain without foreclosing public deliberation. In this way, the Court has served a valuable catalytic function.

I do not claim that the Court has been self-conscious about its role. But some of the justices, especially Justices O'Connor and Powell, have undoubtedly been aware of the difficulty and variety of the affirmative action problem and have chosen a casuistical approach for this reason. ${ }^{72}$ Nor do I claim that the current public interest in affirmative action owes its origin to Supreme Court decisions. There are undoubtedly a wide range of factors that could be said to have played a catalytic role. All I contend is that the Court's decisions have been among the factors that have both kept affirmative action in the public eye and helped focus the public on issues of principle and policy. And to the extent that those effects have been salutary, the Court's practice here bears on other meandering paths in the past, ${ }^{73}$ and also on future practices, perhaps in the area of discrimination on the basis of sexual orientation, where a degree of casuistry also makes a good deal of sense. ${ }^{74}$

I cannot offer here a full discussion of when casuistry in the interest of public deliberation is a desirable strategy for the Court, ${ }^{75}$ but a few brief remarks may be helpful. The casuistical approach makes inost sense when the Court is uncertain or divided about whether any broad rule is constitutionally sound. It follows that in the affirmative action context, the Court's approach is inore attractive to those who are unsure about the constitutional status of affirmative action. For those who believe that it is per se invalid, or clearly acceptable in all circuinstances,

71. See Cass R. Sunstein, Free Markets and Social Justice ch. 2 (forthcoming 1997); Cass R. Sunstein, Social Norms and Social Roles, 96 Colum. L. Rev. 983 (1996).

72. See Adarand, 115 S. Ct. at 2108-12; Croson, 488 U.S. at 509 (O'Connor, J.) (plurality opinion); Bakke, 438 U.S. at 269-320 (Powell, J.).

73. The Court's treatment of federalism provides a notable example. The recent decision in United States v. Lopez, 115 S. C. 1624 (1995), turned on a set of factors-the absence of clear findings from Congress, the traditionally local nature of education, the fact that the relevant guns did not have to travel in interstate commerce, and the fact that commercial activity was not involvedrather than a lucid rule. Whether or not Lopez was right, it might be taken as a salutary signal to Congress and the nation that the Commerce Clause is limited, and that public deliberation should attend to those limitations.

74. See Cass R. Sunstcin, Homosexuality and the Constitution, 70 IND. LJ. 1, 23-27 (1994) (defending the view that a casuistic approach by the Court is appropriate in this area of the law).

75. For more detail, see Sunstein, supra note 2. 
judicial casuistry would be harder to defend. Casuistry will seem most sensible to those who believe that the relevant outcome should turn on particular facts. In the affirmative action context, we might think that a rigid quota system is worse than "race as a factor," or that universities have special reasons to engage in race-conscious programs.

Equally important, the argument for casuistry, as a catalytic approach, is strengthened by a judgment that judicial decisions will in fact spur, or at least be a healthy part of, ongoing processes of public deliberation. The argument becomes even stronger if those processes at least have the potential to function well. If this is so, judicial casuistry may promote, rather than undermine, the system of democratic deliberation. If, on the other hand, public deliberation is unlikely in any event, or likely to operate very badly, a more rule-bound approach to the Constitution would be better. Obviously there are empirical issues here that I have not resolved.

On these grounds, we can see how the Court's casuistical decisions, defended in the way I have here, might best be criticized. Perhaps the Constitution is sensibly interpreted to ban all affirmative action programs (though I have suggested that this would be a most adventurous reading). Perhaps the Constitution is best understood not to draw such programs imto question at all. Or perhaps democratic processes have been working very well without the Court, and the Court's decisions have been marginally relevant, or have even helped to facilitate distortions of democratic deliberation. I do not believe this judgment could be supported, but it suggests the direction in which a challenge to the Court's approach might move. It suggests, too, how judicial casuistry might be evaluated im the context of such issues as discrimination on the basis of sexual orientation. I believe, for example, that most such discrimination is unacceptable under the Equal Protection Clause. But it may very well make sense for the Court to proceed slowly, cautiously, and in a case-specific way, because of the variety of possible settings, the practical need to build on democratic judgments, and the value of judicial humility $m$ the face of so controversial a public issue, one that is now receiving considerable public attention. ${ }^{76}$

\section{VI}

\section{Affirmative Action, Deliberative Government, AND THE REFERENDUM}

The suggestion that the Court has helped catalyze public debate should not by any means be taken as a claim that with respect to

76. Id. 
affirmative action, the democratic process has been or is now working well. With "norm cascades"-large shifts in current norms-there is a risk that outcomes will be based on sensationalistic anecdotes, on factual misperceptions, or, worse, on simple racism and hatred. Undoubtedly, objections to affirmative action programs are often well-motivated; it would be ludicrous to think that such objections are necessarily rooted in racial prejudice. But appeals to racism, usually tacit, are a large part of the debate. Some people might think that affirmative action is an unpromising area for public deliberation precisely because of the likelihood that racist motivations will be at work. If this is an unpromising area for public deliberation, the argument for a catalytic effort from the Court is of course weakened, and judges might attempt to resolve the problem on other grounds.

The relevant risks are especially severe in the context of a referendum, which bypasses ordinary filters of political representation and hence raises special risks. ${ }^{77}$ Referenda may well be based on inadequate information and on popular passions that are insufficiently influenced by reason-giving and understanding of context. ${ }^{78}$ This was of course a relevant concern in the framing period. ${ }^{79}$

Much national attention is now focused on a referendum proposal in California desigued to eliminate preferential treatment based on race. ${ }^{80}$ Political processes in California on this issue do not appear to be deliberative. The American system is one of representative rather than direct democracy, partly because of a judgment that political deliberation can be best promoted through a representative system. ${ }^{81}$ If judicial decisions stimulate poorly functioning referendum processes, little will be gained.

In the context of affirmative action in particular, there is a danger that referendum outcomes will not be based on a careful assessment of facts and values, but instead on crude "we-they" thinking. This is a

77. See James S. Fishikin, Democracy and Deliberation: New Direction for Democratic ReForm (1991).

78. Id. at 58-59.

79. See The Federazist No. 10 (James Madison).

80. In 1996, Californians will vote on the following anti-affirmative action amendment to the state constitution (dubbed by its supporters as the "California Civil Rights Initiative"):

Neither the State of Califomia nor any of its political subdivisions or agents shall use race, sex, color, ethnicity, or national origin as a criterion for either discriminating against, or granting preferential treatment to, any individual or group in the operation of the State's system of public employment, public education, or public contracting.

California Civiz Rights initiative, reprinted in California Senate Office of Reszarch, The Status of Affirmative Action in California (1995).

81. See The Federalist No. 10, supra note 79; Joseph M. Bessette, The Mild Voice of Reason: Deliberative Democracy and American National Government (1994). 
danger in the context of race. It is not my purpose here to evaluate that risk. But if a catalytic role from the Court serves to intensify poorly functioning majoritarian processes, that role may be nothing to celebrate. Both exercises of statesmanship and institutional correctivesdisplacing the referendum process with more insulated bodies-inay be in order. Hence, it is appropriate to assemble politically insulated groups to try to compile information about the actual effects of affirmative action programs. ${ }^{83}$

Unfortunately, it is unclear whether the Supreme Court can do a great deal to nake things better. Some people have suggested that the Court might review the outcomes of referenda with an unusually high degree of skepticism. ${ }^{84}$ There is some sense in this suggestion. An approach of this kind can find structural support in the Constitution, which is rooted in faith in representation, and in the Constitution's most fundamental underlying concerns. It is plausible to say that the Court should be mildly more receptive to a constitutional challenge when legislation has come through referenda. But no provision of the Constitution specifically authorizes judges to regard the outcomes of referenda as less legitimate than the outcones of representative processes, and in any case it is not, under current law, easy to see how someone inight challenge a ban on affirmative action on these constitutional grounds. ${ }^{85}$

\section{CONCLUSION}

In this essay, I have tried to connect two ideas. The first involves the disjunction between private beliefs and public statennents-a disjunction that stems from social norms that can discourage honest public argument about public issues and in that way undermine values that animate the First Alnendinent itself. The second involves the catalytic

82. See, e.g., the amendment to the Colorado Constitution at issue in Romer v. Evans, 114 U.S. (1996), which provides in pertinent part:

Neither the State of Colorado, through any of its branches or departments, nor any of its agencies, political subdivisions, municipalities or school districts, shall enact, adopt or enforce any statute, regulation, ordinance or policy whereby homosexual, lesbian or bisexual orientation, conduct, practices or relationships shall constitute or otherwise be the basis of or entitle any person or class of persons to have or claim any minority status, quota preferences, protected status or claim of discrimination.

Id. at 1623 (quoting Amend. 2 to CoLo. CoNST., art. II, § 2). The Supreme Court struck down the amendment as unconstitutional under the Equal Protection Clause.

83. Cf. Stephen Breyer, Breaking the Vicious Circle: Towards Effective Risk REGULATION (1993) (discussing an institutional remedy for regulatory failure, through increasing the power of specialists to allocate resources in sensible ways).

84. For a discussion of these suggestions, see Julian N. Eule, Judicial Review of Direct Democracy, 99 YALE L.J. 1503 (1990).

85. After Washington v. Davis, 426 U.S. 229 (1976), it is clear that affirmative action is not required by the Constitution exeept in eertain narrow circumstances, such as when race-conscious remedies are constitutionally required for remedial purposes. See Swann v. Charlotte-Mecklenberg Bd. of Educ., 402 U.S. 1 (1971). 
animate the First Amendment itself. The second involves the catalytic role of the Supreme Court. This role is ordinarily thought to involve three principal powers: validating or invalidating laws, and refusing to hear cases. But the Court has a fourth power-the authority to issue highly casuistical rulings that do not settle much, but that operate as a kind of "remand" to the public, alerting people to the existence of hard issues of principle and policy. In the affirmative action context, the Court, whether or not intentionally, has done precisely this. It has said little that is authoritative. It has, however, helped trigger public debate, with, perhaps, an understanding on the part of some of the Justices that until recently, the debate was neither broadly inclusive nor properly deliberative-and that it did not honestly reflect people's underlying concerns. In other words, the Court can be taken to have responded to the fact that social norms have helped prevent open public discussion, and to have tried to promote such a discussion.

From these points, it would be possible to celebrate what many have seen as the Court's indefensible course of rule-free judgment. Perhaps the Court has refused to foreclose an issue on which the political branches should have the final say, but nonetheless played a valuable role in ensuring that the political branches actually give the issue the attention that it warrants. Certainly, the Court's decisions have inspired a great deal of media attention and placed a kind of public spotlight on affirmative action.

I think that ideas of this sort generally support a degree of casuistry in some areas of constitutional law, and that casuistry makes a great deal of sense in the context of hard issues on which the nation is sharply divided. But the approach may be too optimistic in the particular context of affirmative action. If it is too optimistic, this is so either because affirmative action is not problematic from the standpoint of policy and principle, or because the political process, realistically speaking, will not be deliberative at all, but instead will serve as a forum for sloganeering, mutual suspicion, and racial prejudice.

Neither of these reservations can be easily dismissed. But in light 'of the wide range of programs labelled "affirmative action," the first reservation seems too starkly stated. Even those who approve of affirmative action should recognize that some programs are unfair and do not fulfill their intended purposes. In any case, a public discussion would serve many valuable functions. It is much too soon to know whether the second reservation is warranted. But it does seem safe to say that the area of affirmative action casts a new light on the role of the Supreme Court. It shows that the Court's catalytic role can help trigger public debate and heretofore silent protest where debate might otherwise be absent. From the standpoint of deliberative democracy, what is 
catalyzed may be nothing to celebrate, at least in the context of race. But remedies for that large problem would take me well beyond the present discussion. 
